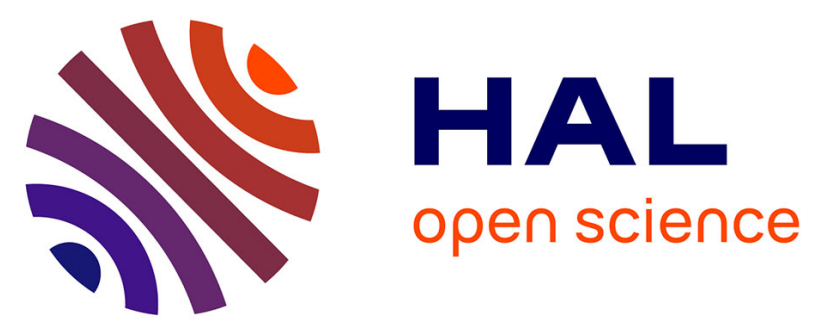

\title{
Erratum: Measuring the wavenumber of guided modes in waveguides with linearly varying thickness [J. Acoust. Soc. Am. 135(5), 2614-2624 (2014)]
}

Ludovic Moreau, Jean-Gabriel Minonzio, Maryline Talmant, Pascal Laugier

\section{- To cite this version:}

Ludovic Moreau, Jean-Gabriel Minonzio, Maryline Talmant, Pascal Laugier. Erratum: Measuring the wavenumber of guided modes in waveguides with linearly varying thickness [J. Acoust. Soc. Am. 135(5), 2614-2624 (2014)]. Journal of the Acoustical Society of America, 2014, 136 (2), pp.945. $10.1121 / 1.4884766$. hal-01394320

\section{HAL Id: hal-01394320 \\ https://hal.sorbonne-universite.fr/hal-01394320}

Submitted on 9 Nov 2016

HAL is a multi-disciplinary open access archive for the deposit and dissemination of scientific research documents, whether they are published or not. The documents may come from teaching and research institutions in France or abroad, or from public or private research centers.
L'archive ouverte pluridisciplinaire HAL, est destinée au dépôt et à la diffusion de documents scientifiques de niveau recherche, publiés ou non, émanant des établissements d'enseignement et de recherche français ou étrangers, des laboratoires publics ou privés. 


\section{Erratum: Measuring the wavenumber of guided modes in}

\section{waveguides with linearly varying thickness}

Ludovic Moreau, Jean-Gabriel Minonzio, Maryline Talmant, and Pascal Laugier

Laboratoire d'Imagerie Biomédicale, UPMC, UMR CNRS 7371 - INSERM U1146, 15 rue de l'école de médecine F-75006, Paris, France

June 5th, 2014 
There is an error in the phase term of Eq. (13). The correct phase is expressed as an integral. ${ }^{1,2}$ Thus, the corrected expression of Eq.(13) is

$$
e_{m}^{t e s t}(k, \mathcal{E})=\frac{1}{\sqrt{M}} e^{i \int_{x_{1}^{R}}^{x_{m}^{R}} k^{t e s t}(x) d x}
$$

with $k^{\text {test }}(x)$ defined with coefficients $k$ and $\varepsilon$ of a first order Taylor expansion following Eq. (10) as

$$
k^{\text {test }}(x)=k\left(1+\frac{\varepsilon}{p} x\right)
$$

Thus, in a first order Taylor expansion, it implies that Eq. (13) also expresses as

$$
e_{m}^{t e s t}(k, \mathcal{\varepsilon})=\frac{1}{\sqrt{M}} e^{i\left(k\left(x_{m}^{\mathrm{R}}-x_{1}^{\mathrm{R}}\right)+\frac{1}{2} k \frac{\varepsilon}{p}\left(x_{m}^{\mathrm{R}}-x_{1}^{\mathrm{R}}\right)^{2}\right)} \text {. }
$$

Then, the corrected expression of Eq. (15) is

$$
\left\langle\mathbf{e}^{\text {test }}(k, \varepsilon) \mid \mathbf{U}_{1}\right\rangle=\frac{1}{M} \sum_{m=1}^{M} \exp \left[i\left(\left(k_{0}-k\right)\left(x_{m}^{\mathrm{R}}-x_{1}^{\mathrm{R}}\right)+\frac{1}{2}\left(k_{0} \frac{\varepsilon_{0}}{p}-k \frac{\varepsilon}{p}\right)\left(x_{m}^{\mathrm{R}}-x_{1}^{\mathrm{R}}\right)^{2}\right)\right] \text {. }
$$

This error does not affect the estimation of the wavenumbers (Fig. 5) and the conclusion of the paper. However, it affects the estimation of the deviation term $\varepsilon\left(x_{0}, f\right)$ by a factor $1 / 2$. It explains the discrepancy observed in Fig. 6 between theoretical and experimental values of the deviation term $\varepsilon\left(x_{0}, f\right)$. In the corrected figure, the discrepancy is reduced.

\section{Acknowledgment}

The authors would like to thank Dr. Vincent Pagneux (Laboratoire d'Acoustique de l’Université du Maine, Le Mans, France) about his fruitful comments on Eq. (13). 
${ }^{1}$ V. Pagneux and A. Maurel, "Lamb wave propagation in elastic waveguides with variable thickness," Proceedings of the Royal Society A: Mathematical, Physical and Engineering Science 462(2068), 1315-1339 (2006).

${ }^{2}$ L. De Marchi, A. Marzani, and M. Miniaci, "A dispersion compensation procedure to extend pulse-echo defects location to irregular waveguides," NDT \& E International 54, 115-122 (2013).

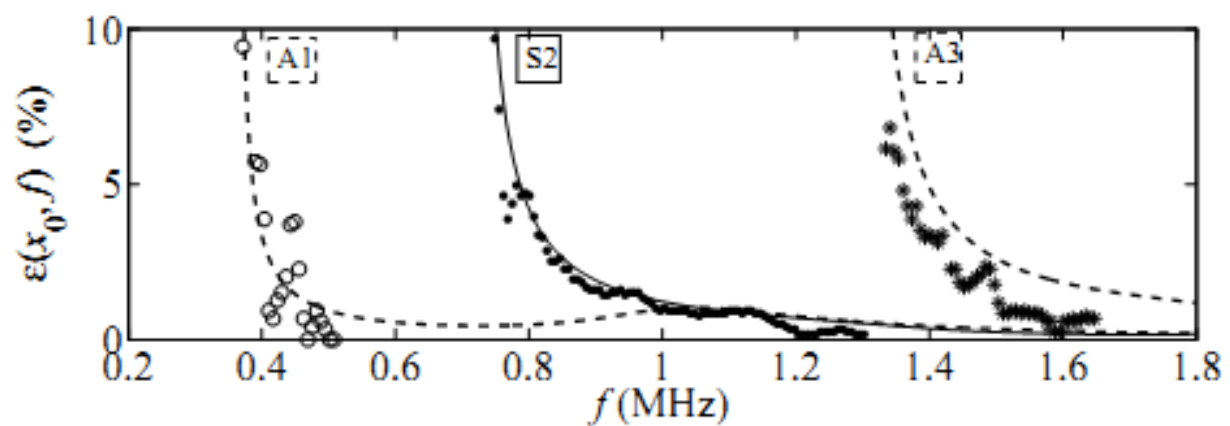

(a)

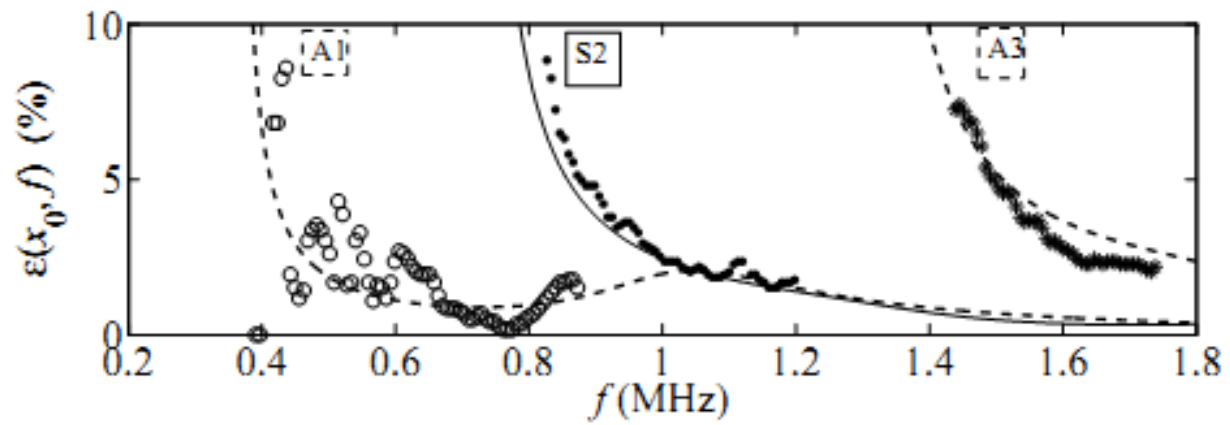

Figure 6. Theoretical (continuous and dashed lines) and experimental values of the deviation term $\varepsilon\left(x_{0}, f\right)$ for $\alpha=1^{\circ}$ (a) and $\alpha=2^{\circ}$ (b), for modes A1 (circles), S2 (stars) and A3 (dots) for direction "-". 


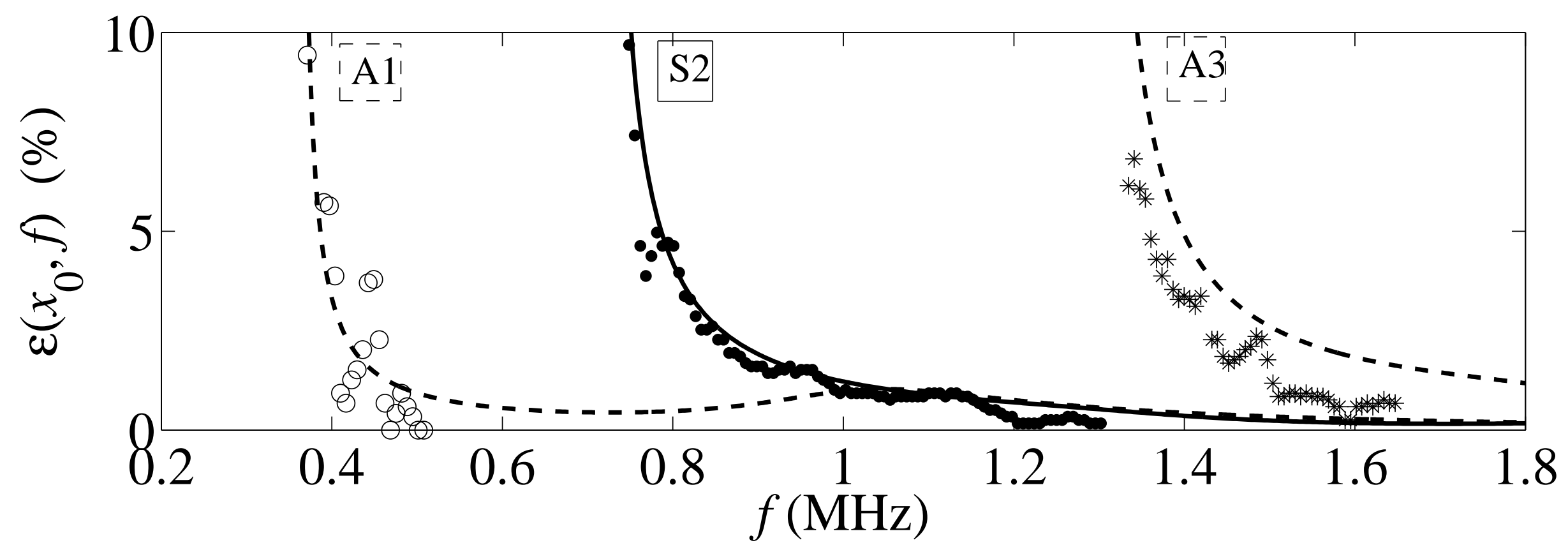

(a)

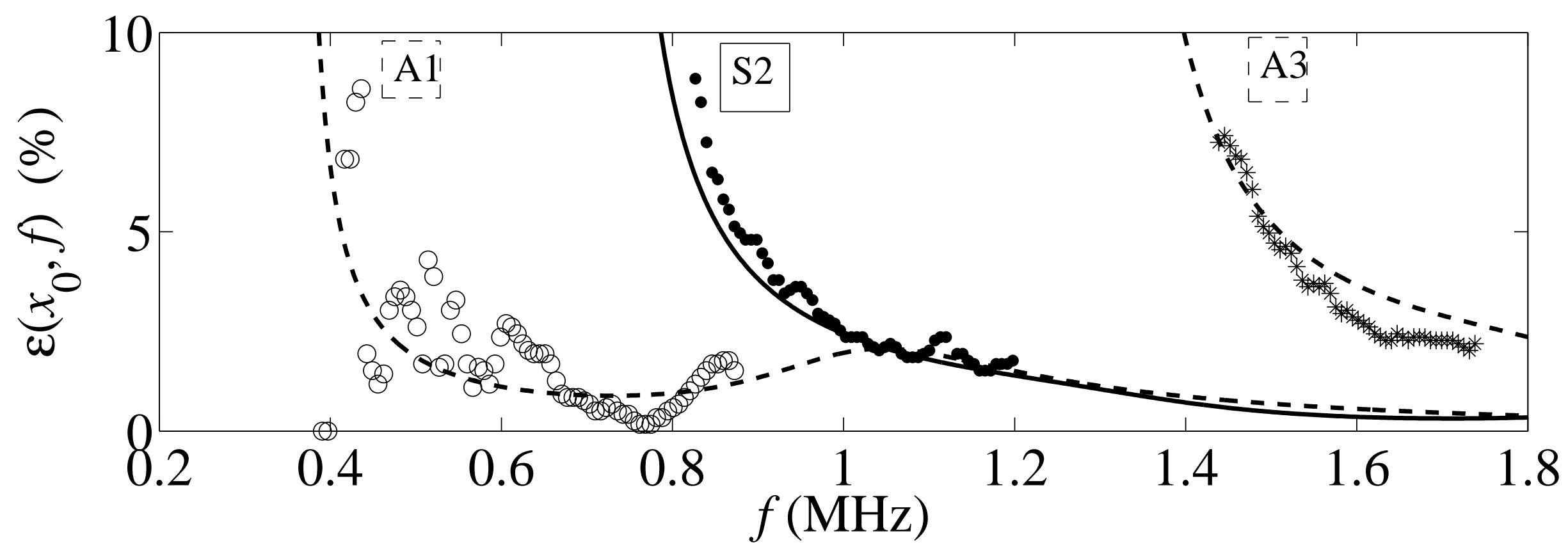

(b) 